Bajopas Volume 2 Number 2 December, 2009

$$
\begin{aligned}
& \begin{array}{l}
\text { Bayero Journal of Pure and Applied Sciences, 2(2): } 66 \text { - } 69 \\
\text { Received: August, } 2009 \\
\text { Accepted: October, } 2009
\end{array} \\
& \text { MICROBIOLOGICAL QUALITY OF SPICE USED IN THE PRODUCTION OF } \\
& \text { KILISHI A TRADITIONALLY DRIED AND GRILLED MEAT PRODUCT }
\end{aligned}
$$

\section{MICROBIOLOGICAL QUALITY OF SPICE USED IN THE PRODUCTION OF KILISHI A TRADITIONALLY DRIED AND GRILLED MEAT PRODUCT}

\author{
Shamsuddeen U.
}

Department of Biological Sciences, Bayero University, Kano Nigeria.

e-mail- msdeen1@yahoo.com

\begin{abstract}
Study was carried out on the microbiological quality of the spice mix used in the production of Kilishi. Twenty samples were analyzed. The analyses included; aerobic mesophilic bacterial count, staphylococcal count, fungal count, coliform count, detection of E. coli, Salmonella spp and Clostridium perfringens. The result of the analysis showed that the samples had a mean aerobic plate count, staphylococcal count and fungal count of $2.96 \times 10^{8}, 1.73 \times 10^{7}$, and $1.04 \times 10^{5} \mathrm{cfu} / \mathrm{g}$ respectively. Coliform MPN of $>2400 / g$. E. coli was detected in one of the samples, Salmonella spp one sample and Clostridium perfringens from four samples. The counts obtained were higher than the maximum acceptable levels provided by the Food and Agriculture organization (FAO) of the United Nations. It is therefore recommended that strict hygienic measures should be observed during the mixing of the spice in order to reduce the microbial load to an acceptable level.
\end{abstract}

Key words: Microbiological, Quality, spice, kilishi.

\section{INTRODUCTION}

Kilishi is a sun dried spiced and grilled meat snack that can be kept for considerably long time without getting spoiled due to its dry nature. Application of spice is one of the most important stages during the production of kilishi because it is a critical control point (Shamsuddeen and Ameh, 2008).

Spices could be defined as the natural vegetable products or mixtures thereof, without any extraneous matter that is used for flavouring, seasoning and imparting aroma to foods International Standards Organization (ISO, 1972). Spices like other food substances, may carry some bacteria, yeasts, moulds spores and even some insects. The predominant flora is generally composed of aerobic spore and non spore forming bacteria, indicator organisms and some pathogens may also be found International Commission on Microbiological Specifications for Foods (ICMSF, 1986). Coliforms were isolated and characterized to be $E$. coli, Klebsiella $s p p$, Pectobacterium spp and Enterobacter (Patel et. al., 1976).

According to Frazier and Westhoff (2006), spices do not have a marked bacteriostatic effect in the concentrations used in meat products and they may even serve as source of contamination of processed product. Occurrence of microorganisms that are potentially pathogenic in spices used in suya preparation is considered as major cause of gastrointestinal disturbances resulting from the consumption of suya in Nigeria (Ejeikwu and Ogbonna, 1998). According to Price and Schweigert, (1971), unless spices are treated to reduce their microbial content, they may add high numbers and undesirable kind of organisms to food in which they are used.
Spice ingredients are thought to have some antimicrobial activities, and yet meat treated with spices have high microbial load (Shamsuddeen and Ameh, 2008). It is for this reason therefore, this research was set up with the aim of investigating the microbiological quality of the spice used in the production of kilishi so that recommendation would be made based on the results obtained.

\section{METHODOLOGY}

Sample collection

Samples of spice mixture for kilishi production were collected from Dandalin Fagge at Fagge Local Government Area of Kano State. The mixture is composed of ginger, cloves, West African black pepper, hot pepper, groundnut, salt and seasoning. Twenty (20) Samples were collected using a sterile beaker, on different occasions and sample was taken to the laboratory immediately for analysis.

\section{Sample Preparation and Serial Dilution}

The sample preparation was carried out according to the method described by FAO (1979). In this method, $25 \mathrm{~g}$ of sample (spice) was weighed and homogenized by blending in $225 \mathrm{ml}$ peptone water at $15,000-20,000$ rpm. This was labeled as $1: 10$ dilution which is also the stock or the homogenate. This was further serially diluted to $1: 10^{7}$.

\section{Total Aerobic Plate Count}

This was carried out according to the method of Adullahi et. al., (2004). One milliliter (1ml) of inoculum from $10^{-3}, 10^{-4}, 10^{-5}, 10^{-6}$ and $10^{-7}$ dilutions were transferred into duplicate Petri dishes which were labeled accordingly. 
Bajopas Volume 2 Number 2 December, 2009

This was followed by pouring aseptically about 20$25 \mathrm{ml}$ of molten nutrient agar. The inoculated was mixed by swirling the plates and later allowed to solidify. The plates were incubated at $37^{\circ} \mathrm{C}$ for $24 \mathrm{hrs}$. After incubation, plates containing 30-300 colonies were selected and the colonies counted and recorded. The average was taken and the number obtained was multiplied by inverse of the dilution factor. This gave the number of colony forming units per gram of each sample (cfu/g).

\section{Enumeration and Detection of Staphylococcus aureus}

This was carried out according to Abdullahi et. al., (2004). A quanty $(0.25 \mathrm{ml})$ of inocula from $10^{-2}, 10^{-3}$, $10^{-4}, 10^{-5}, 10^{-6}$ and $10^{-7}$ dilutions were transferred into duplicate Petri dishes which were labeled accordingly. This was followed by pouring aseptically about 20$25 \mathrm{ml}$ of molten Baird Parker agar (Biotek). The plates were incubated at $37^{\circ} \mathrm{C}$ for $24 \mathrm{hrs}$. Plates containing 30-300 black colonies were selected and the colonies counted. The average was taken and the number obtained was multiplied by four and then by the inverse of the dilution factor. This gave the number of colony forming units per gram of a sample (cfu/g). Plates of mannitol salt agar were inoculated and incubated at $35^{\circ} \mathrm{C}$ for $24 \mathrm{hrs}$. Following incubation, mannitol fermenting organisms which showed a yellow zone surrounding their growth were isolated onto agar slants for biochemical tests.

\section{Enumeration and Identification of Yeast and Mould}

This was carried out according to the method of FAO (1979). One millilitre $(1 \mathrm{ml})$ of inocula from $10^{-3}, 10^{-4}$, $10^{-5}, 10^{-6}$ and $10^{-7}$ dilutions were transferred into duplicate petri dishes which were labeled accordingly. This was followed by pouring aseptically about 15$20 \mathrm{ml}$ of molten malt extract agar. The inoculated medium was mixed by swirling the plates and later allowed to solidify. The plates were incubated at 20$25^{\circ} \mathrm{C}$ for 5 days. After incubation, plates containing 30-300 colonies were selected and the colonies counted. The average was taken and the number obtained was multiplied by the inverse of the dilution factor. This gave the number of colony forming units per gram of a sample (cfu/g).

\section{Enumeration and Detection of Coliforms}

This was carried out according to method described by Atlas, (1997). In this method, a set up consisting of 9 test tubes each containing $9 \mathrm{ml}$ of lactose broth and an inverted Durham tube, were autoclaved to sterilize and expel air. Inoculation was made from the serially diluted samples as follows: From the $1: 10$ dilution, $1 \mathrm{ml}$ of inoculum was transferred to each of the first three of the 9 test tubes containing $9 \mathrm{ml}$ of lactose broth. Then $1 \mathrm{ml}$ also was transferred from 1:100 dilution to each of the second set of three test tubes of lactose broth and finally $1 \mathrm{ml}$ of inoculum was transferred from $1: 1000$ dilution to each of the last three tubes. All the 9 test tubes were incubated at $37^{\circ} \mathrm{C}$ for 24 hours and another 24 hours in the absence of gas (presumptive test). Following 24 hrs of incubation the tubes were observed for gas production and the number of gas positive tubes was compared with the most probable number (MPN) table to estimate the most probable number of coliforms per gram of sample. A loop full of inoculum from gas positive tubes was streaked on to Eosine methylene blue (EMB) agar plate and incubated at $37^{\circ} \mathrm{C}$ for $24 \mathrm{hrs}$. Following incubation, colonies which formed bluish black colour with green metallic sheen, and reddish colonies were noted and isolated on agar slants. This is called the confirmatory test. Also colonies showing metallic sheen on EMB, were sub cultured into tubes of lactose broth and incubated at $37^{\circ} \mathrm{C}$. The tubes were observed after $24 \mathrm{hrs}$., for gas production. This is the completed test for fecal coliforms.

\section{Detection of Clostrdium perfringens}

This was carried out according to method described by Cheesbrough (2000). The homogenate was streaked onto neomycin blood agar and incubated anaerobically at $37^{\circ} \mathrm{C}$ for 24 hours. Following anaerobic incubation, the plates were checked for large $\beta$-haemolytic colonies.

\section{Detection of Salmonella}

This was carried out according to FAO (1979). The homogenate was incubated at $37^{\circ} \mathrm{C}$ for $20 \mathrm{hrs}$. After incubation, $10 \mathrm{ml}$ was transferred into $100 \mathrm{ml}$ selenite cystine medium and incubated at $37^{\circ} \mathrm{C}$ for 24 hours (enrichment). A loopfull from the enrichment medium was streaked onto brilliant green agar (BGA) plates and incubated at $37^{\circ} \mathrm{C}$ for $24-48 \mathrm{hrs}$. The colonies were Gram-stained and observed for motility.

\section{RESULTS}

The result of the study is presented in Table 1 . The spice samples analyzed had aerobic plate count, staphylococcal count and fungal count of $2.96 \times 10^{8} \mathrm{cfu} / \mathrm{g}, \quad 1.73 \times 10^{7} \mathrm{cfu} / \mathrm{g}$ and $1.04 \times 10^{5} \mathrm{cfu} / \mathrm{g}$ respectively. The coliform count was $>2400$ for each sample. E. coli was detected in one sample, Salmonella spp, one sample and Clostridium perfringens was detected in four samples. 
Bajopas Volume 2 Number 2 December, 2009

Table 1: Microbiological analysis of spice samples

\begin{tabular}{|c|c|c|c|c|c|c|c|}
\hline S/No. & $\begin{array}{c}\text { APC } \\
(\mathrm{cfu} / \mathrm{g})\end{array}$ & $\begin{array}{c}\mathrm{SC} \\
(\mathrm{cfu} / \mathrm{g})\end{array}$ & $\begin{array}{c}\mathrm{FC} \\
(\mathrm{cfu} / \mathrm{g})\end{array}$ & $\begin{array}{c}\mathrm{CC} \\
(\mathrm{MPN} / \mathrm{g})\end{array}$ & E. coli & Salmonella & C. perf \\
\hline 1 & TNTC & $1.72 \times 10^{6}$ & $1.03 \times 10^{5}$ & $>2400$ & - & - & - \\
\hline 2 & TNTC & $1.62 \times 10^{7}$ & $1.05 \times 10^{4}$ & $>2400$ & - & - & + \\
\hline 3 & $2.11 \times 10^{9}$ & $2.20 \times 10^{7}$ & $3.30 \times 10^{4}$ & $>2400$ & - & - & - \\
\hline 4 & $2.21 \times 10^{8}$ & $1.12 \times 10^{7}$ & $1.04 \times 10^{5}$ & $>2400$ & - & - & - \\
\hline 5 & $1.11 \times 10^{9}$ & $1.60 \times 10^{6}$ & $1.01 \times 10^{5}$ & $>2400$ & - & - & - \\
\hline 6 & $4.90 \times 10^{8}$ & $3.30 \times 10^{7}$ & $1.03 \times 10^{5}$ & $>2400$ & - & - & + \\
\hline 7 & TNTC & $1.11 \times 10^{7}$ & $5.50 \times 10^{4}$ & $>2400$ & - & - & - \\
\hline 8 & $2.22 \times 10^{9}$ & $7.10 \times 10^{6}$ & $1.72 \times 10^{5}$ & $>2400$ & - & - & - \\
\hline 9 & TNTC & $1.19 \times 10^{7}$ & $1.05 \times 10^{5}$ & $>2400$ & - & - & - \\
\hline 10 & $1.15 \times 10^{9}$ & $1.10 \times 10^{7}$ & $1.43 \times 10^{5}$ & $>2400$ & - & - & - \\
\hline 11 & TNTC & $1.72 \times 10^{7}$ & $1.60 \times 10^{5}$ & $>2400$ & - & - & + \\
\hline 12 & TNTC & $1.71 \times 10^{7}$ & $1.03 \times 10^{5}$ & $>2400$ & - & - & - \\
\hline 13 & TNTC & $2.11 \times 10^{7}$ & $1.93 \times 10^{4}$ & $>2400$ & - & - & - \\
\hline 14 & $9.60 \times 10^{8}$ & $1.13 \times 10^{7}$ & $7.00 \times 10^{4}$ & $>2400$ & - & & - \\
\hline 15 & TNTC & $2.11 \times 10^{6}$ & $1.00 \times 10^{5}$ & $>2400$ & - & - & - \\
\hline 16 & $5.60 \times 10^{9}$ & $1.17 \times 10^{7}$ & $1.11 \times 10^{5}$ & $>2400$ & + & + & - \\
\hline 17 & TNTC & $1.02 \times 10^{7}$ & $1.04 \times 10^{5}$ & $>2400$ & - & - & - \\
\hline 18 & $2.21 \times 10^{9}$ & $1.72 \times 10^{7}$ & $1.23 \times 10^{5}$ & $>2400$ & - & - & - \\
\hline 19 & $3.90 \times 10^{9}$ & $1.72 \times 10^{7}$ & $1.10 \times 10^{5}$ & $>2400$ & - & - & - \\
\hline 20 & $1.55 \mathrm{E} 10$ & $9.40 \times 10^{6}$ & $2.50 \times 10^{5}$ & $>2400$ & - & - & + \\
\hline Means & $2.96 \times 10^{9}$ & $1.73 \times 10^{7}$ & $1.04 \times 10^{5}$ & $>2400$ & & & \\
\hline
\end{tabular}

Key:

$+=$ Detected,$-=$ Not detected, $\mathrm{APC}=$ Aerobic plate count, $\mathrm{SC}=$ Staphylococcal count, $\mathrm{FC}=\mathrm{Fungal}$ count, $\mathrm{CC}=$ Coliform count, TNTC $=$ Too numerous to count at all the dilutions made.

$\mathrm{cfu} / \mathrm{g}=$ colony forming unit per gram.

$\mathrm{MPN} / \mathrm{g}=$ Most probable number/gram.

\section{DISCUSSION}

The mean values of the obtained from the aerobic mesophylic count, staphylococcal and fungal counts from the spice used in the production of kilishi were high. This is because aerobic plate count of $10^{8} \mathrm{cfu} / \mathrm{g}$, staphylococcal count of $10^{7} \mathrm{cfu} / \mathrm{g}$ and fungal count of $10^{5} \mathrm{cfu} / \mathrm{g}$ are all high. These values are higher than the maximum acceptable levels provided by the Food and Agriculture organization of the United Nations according to which the aerobic plate and fungal counts of spices should not be greater than $10^{6}$ and $10^{4} \mathrm{cfu} / \mathrm{g}$ respectively.

The high staphylococcal count is also a point of concern since the growth of Staphylococcus aureus to a population of $10^{5} \mathrm{cfu} / \mathrm{g}$ is considered necessary for the production of $1 \mu \mathrm{g}$ of enterotoxin sufficient to cause intoxication if such food is consumed, However ICMSF (1978) indicated that $10^{6}$ cells of $S$. aureus/gram is required to present the risk of intoxication. Another point of deviation from FAO standard in the spice is the high coliform count and the presence of $E$. coli in particular, which is an indication of improper and inadequate hygienic practices. Shamsuddeen and Ameh, (2008) also reported the presence of high bacterial load as well as presence of coagulase positive Staphylococci and E. coli in kilishi from Kano metropolis.
The high bacterial load in the spices is an indication of unhygienic practices during their preparation. Contaminating organisms might have come from hands of handlers (Bukar et al., 2009), the utensils from air and even from the spice ingredients themselves because according to Frazier and Westhoff (2006), spices may even serve as source of contamination of processed product. Price and Schweigert, (1971), reported that unless spices are treated to reduce their microbial content, they may add high numbers and undesirable kind of organisms to food in which they are used.

\section{Conclusion and Recommendations}

The microbial loads of spice used in kilishi production is high, there was also in the spice indicator organisms and organisms that are potentially pathogenic. It could therefore be recommended that;

- Spices should be produced under strict hygienic measures.

- The spice should be subjected to treatment that would reduce their microbial load. This is to avoid the introduction of undesirable kinds of organisms that might bring about spoilage and contamination. 


\section{REFERENCES}

Abdullahi, I. O., Umoh, V. J., Ameh, J. B. and Galadima M. (2004): Hazards associated with Kilishi preparation in Zaria, Nigeria. Nigerian Journal of Microbiology. Vol. 18 (1-2): 339-345).

Atlas, R. M. (1997). Principles of Microbiology second edition C. Brown publishers. Pp 802-803.

Bukar, A., Yusha'u, M. and Adikwu, E. M. (2009). Incidenc and Identification of Potential Pathogens on Hands of Personel in some small scale food Industries in Kano Metropolis. Biological and Environmental Sciences Journal for the Tropics. 6(4).

Cheesebrough, M. (2000). District Laboratory practice in Tropical Countries. Part 2. Cambridge University Press. Pp76-100.

Ejeikwu, E. O. and Ogbonna, C. I. C. (1998). Species of microorganisms associated with the ingredients used in the preparation of the Nigerian take away roasted meat (Suya). Zuma Journal of Pure and Applied Sciences. 1(1): 7-10.

Food and Agriculture Organization of the United Nations FAO (1979): Manuals of food quality contro/4. Microbiological analysis. D1-D37.

Frazier, W. C. and Westthroff, W. C. (2006). Food microbiology $3^{\text {rd }}$ Edition, McGraw Hill Publishing Company Limited New York. Pp163-165, 223-236, 419-543.
International Commission on Microbiological Specifications for Foods (ICMSF) (1986). Microorganisms in food sampling for microbiological analysis: Principle and specific application $2^{\text {nd }}$ Edition. Blackwell Scientific Publications Pp139-140; 213-215.

International Commission on Microbiological Specifications for Foods (ICMSF) (1978). Microorganisms in foods vol 2: Sampling for Microbiological analysis: principle and specific application. University of Toronto Press 110-127.

International Standards Organizatio, (ISO) (1972). Spices and condiments. Women culture Finchized Draft Proposal. Tc-34/Sc-7, 150 Budapest.

Patel, J. D., Krishnaswamy, M. A., and Nair, K. K. S. (1976). Biochemical characteristics of some coliforms isolated from spices. Journal of Food Science Technology. India 13: 37-40.

Price, J. F. and Schweigert B. S. (1971). The science of meat and meat products. $2^{\text {nd }}$ Edition. Published by W. H. Freeman and Company Pp 289.

Shamsuddeen U. and Ameh J. B. (2008): Survey on the possible critical control points in kilishi (a traditional dried and grilled meat snack) produced in kano. International Journal of Bioscience. 3(2): 34-38. 